\title{
ECOTOURISM AS A FACTOR INFLUENCING BEHAVIOUR OF TOURISM MARKET PARTICIPANTS
}

\author{
University School of Physical Education in Wrocław \\ Faculty of Physical Education \\ 1 e-mail: janusz@olearnik.pl \\ 2 e-mail: katarzynabarwicka@gmail.com
}

JANUSZ OLEARNIK, ${ }^{1}$ KATARZYNA BARWICKA ${ }^{2}$

\begin{abstract}
\begin{tabular}{l|l} 
JEL CODES & D91, L83, Z32
\end{tabular}
KEYWORDS tourism, ecotourism, tourism market, market participants' behaviours

ABSTRACT The aim of the paper was to identify the potential impact of ecotourism on tourism market participants. The methodology was based on the research of literature on ecotourism and tourism market, debate, and own reflection. The results prove that ecotourism significantly influences the awareness and attitudes of tourism market participants. It can serve as a tool to facilitate an alliance between tourism and the natural environment. Ecotourism can provide multidimensional advantage to tourists, entrepreneurs, inhabitants, and the nature itself. The paper indicates the directions of further research on ecotourism.
\end{abstract}

\section{Introduction}

The contemporary relations between man and nature are characterized by a greater respect for the natural environment. The relations between people, businesses, and the natural environment are of particular importance for tourism industry, largely based on natural assets. A development of attitudes, behaviours, and activities of ecotourist character is noted nowadays. Ecotourism, a relatively new phenomenon, requires scientific observation and analyses. 
The aim of this article was to indicate the potential impact of the observed ecotourism trends on the awareness, attitudes, and behaviours of tourism market participants. The authors also intended to point at the areas of further research.

\section{Material and methods}

The methodological basis of the paper was literature research, debate, and own reflection. The literature research involved publications on ecotourism by, among others, Blamey (2001), Donohoe, Lu, and Wu (2006), Donohoe and Needham (2006), Fennell (2014), Weaver (2001). Sources referring to ecological awareness (Kollmuss, Agyeman, 2002) were also analysed.

\section{Ecotourism - ideas and assumptions}

The definition of ecotourism has been changing and gradually widening. Table 1 presents examples of the most significant definitions.

Tahle 1. Selected ecotourism definitions

\begin{tabular}{|c|c|}
\hline Source & Definition \\
\hline Ceballos-Lascurain (1987, p. 14) & $\begin{array}{l}\text { Travelling to relatively undisturbed or uncontaminated natural areas with the specific objective } \\
\text { of studying, admiring and enjoying the scenery and its wild plants and animals, as well as any existing } \\
\text { cultural manifestations (both past and present) found in these areas }\end{array}$ \\
\hline Morgan (1999) & $\begin{array}{l}\text { Ecologically sustainable tourism that fosters environmental and cultural understanding, appreciation } \\
\text { and conservation }\end{array}$ \\
\hline $\begin{array}{l}\text { The British Ecotourism Market, } \\
\text { UNWTO (2002) }\end{array}$ & $\begin{array}{l}\text { Ecotourism refers to forms of tourism which have the following characteristics: } \\
\text { All nature-based forms of tourism in which the main motivation of the tourists is the observation and } \\
\text { appreciation of nature as well as the traditional cultures prevailing in natural areas. } \\
\text { - It contains educational and interpretation features. } \\
\text { - It is generally, but not exclusively, organised by specialised tour operators for small groups. } \\
\text { Service provider partners at the destinations tend to be small, locally owned businesses. } \\
\text { - It minimises negative impacts upon the natural and socio-cultural environment. } \\
-\quad \text { It supports the maintenance of natural areas which are used as ecotourism attractions by: } \\
\text { - generating economic benefits for host communities, organisations and authorities managing } \\
\text { natural areas with conservation purposes; } \\
\text { - providing alternative employment and income opportunities for local communities; } \\
\text { increasing awareness towards the conservation of natural and cultural assets, both among } \\
\text { locals and tourists }\end{array}$ \\
\hline $\begin{array}{l}\text { The International Ecotourism } \\
\text { Society (2015) }\end{array}$ & $\begin{array}{l}\text { Responsible travel to natural areas that conserves the environment, sustains the well-being of the local } \\
\text { people, and involves interpretation and education. Education is meant to be inclusive of both staff and } \\
\text { guests }\end{array}$ \\
\hline
\end{tabular}

Source: own study based on sources mentioned in the table.

Numerous researchers (Blamey, 2001, p. 2; Zaręba, 2010, p. 48) maintain that ecotourism derives from sustainable tourism. Others (e.g. Lu, Gursoy, Del Chiappa, 2016, p. 1; Weaver, 2001, p. 2) suggest that it is a form of alternative tourism, as opposed to mass tourism, burdened with many tourist dysfunctions. Some perceive ecotourism as a hybrid of sustainable tourism, nature tourism, and alternative tourism (e.g. Weaver, 2001, p. 2). The diversity of approaches can result from the variety of education, specialization, and experience of the researchers (Koeman, 1998, 
p. 1). Some authors rightly argue that creating one, world-universal definition of ecotourism is impossible for various reasons, e.g. cultural differences (Björk, 2000).

Numerous publications describe the key characteristics of ecotourism (e.g. Butler, 1999; Higham, 2007; Diamantis, 1999; Donohoe et al., 2006; Donohoe, Needham, 2006; Fennell, 2014; The International Ecotourism Society, 2015; Weaver, 2001; Whelan, 2013; Zaręba, 2010). The basic assumptions of ecotourism are presented in Table 2.

Tahle 2. Basic assumptions of ecotourism

\begin{tabular}{|l|l|l|}
\hline \multicolumn{1}{|c|}{ Donohoe et al. (2006) } & \multicolumn{1}{|c|}{ Fennell (2014) } & \multicolumn{1}{c|}{ Donohoe and Needham (2006) } \\
\hline 1. Nature-based & 1. Nature-based & 1. Nature-based \\
2. Preservation/conservation & 2. Sustainability: & 2. Preservation/conservation \\
3. Environmental education & - local participation/benefits, & 3. Environmental education \\
4. Sustainability & - conservation & 4. Sustainability \\
5. Contribution to local community & 3. Education & 5. Distribution of benefits \\
6. Ethics/responsibility & 4. Moral imperative & 6. Ethics/responsibility \\
\hline
\end{tabular}

Source: own elaboration based on sources mentioned in the table.

The application of ecotourism attributes in the behaviours of tourism market participants is manifested by:

- the care of the natural environment;

- consideration for the cultural environment;

- respect for the social environment;

- education in the natural and cultural heritage.

Ecotourism has become a social phenomenon, with a constantly rising popularity (Hawkins, Lamoureux, 2001; The International Ecotourism Society, 1990). Ecotourism is also a trend. According to prognoses (Sharpley, 2006, pp. 7-22), ecotourism can constitute as much as 5\% of holiday travels in the world tourism market by 2024. Researchers observe a constant interest in nature tourism (Balmford et al., 2009; Twining-Ward, Li, Bhammar, Wright, 2018) and an increasing ecological awareness of tourists (Center for Responsible Travel, 2017, p. 7). A new, specific but broad segment of the market is therefore emerging, which opens novel business perspectives.

\section{Potential impact of ecotourism on the hehaviours of tourist services consumers and tour operators}

The following hypothetical areas of ecotourism influence on the behaviours of consumers should be indicated:

1. Defining purposes of tourist travels. Ecotourism allows numerous tourist forms, at the same time imposing some restrictions, such as recreation in the minimally transformed, unpolluted natural environment, personal development and interest stimulation through contacts with local culture, education (including ecological one), isolation from the city noise or everyday problems. Ecotourism ideas can change the traditional pattern of tourist travel aims. This is significant for both tourist services consumers and tour operators. 
2. Decisions concerning the sites and forms of tourist travels. The sites of tourist stays are usually areas of outstanding landscape assets and minimally transformed nature. Potential ecotourist destinations facilitate active recreation and widening knowledge about the place being visited. This does not exclude achieving the aims of ecotourism in tourist centres, provided that a suitable offer of services and forms of spending time is available.

3. Analysing tourist offer details in the context of the man-nature relationship. Consumers compare tourist offers when planning a journey. They should consider criteria reflecting the relationship between man and nature in these analyses. Ecotourism imposes respect for such criteria.

4. Shaping tourists' knowledge and sensitivity with regard to the coexistence of people and the natural environment. In general, ecotourism is a conscious choice of a consumer, based on their already possessed knowledge and sensitivity. There is, though, a group of consumers whose knowledge and sensitivity develop during travels, mainly owing to the experience of appropriately presented heritage interpretation. This group often includes children and youth.

5. Preparing tourist travels with the knowledge of and respect for local cultures. Ecotourism protects the cultural heritage of destinations and the interest of local inhabitants. It requires proper relationship of the tourist and local culture.

6. Respect for the environmental protection rules. An ecotourist should understand and apply the basic rules of pro-ecological behaviours. Ecotourism requires and develops sensitivity towards nature.

As for the impact of ecotourism on the behaviours of tour operators, several hypothetical areas can be indicated:

1. Recognizing the new market segment: consumers, trends, conditioning, prognoses. The market segment is not recognized thoroughly, with a potentially variable group of young consumers of higher ecological sensitivity. Thus, an entrepreneur cannot follow tested paths but ought to find new ways of reaching the potential segment and satisfy its needs.

2. Seeking for ecotourist offers: modifying products and creating new ones. Ecotourism has few verified, traditional market products. To satisfy the ecotourism ideas, one has to create own, highly original products. This requires excellent knowledge of ecotourism standards and inventiveness.

3. Awareness and actions of tourist facilities owners and managers. The market success begins in the minds of entrepreneurs and managers. Ecotourism ideas shape a new generation of people managing business in tourism. They are characterized by a higher ecological awareness and capability to apply it in business; moreover, they often found their business solely on ecological awareness and sensitivity.

4. Tourist facilities staff behaviours and preparedness. Ecotourism raises staff requirements, demands suitable ecological awareness, sensitivity, and ability to influence tourists. These additional requirements are equally significant in a small rural tourist facility and in a hotel. 
5. Adjusting the devices and procedures in tourist facilities. Ecotourism requires the fulfilment of many detailed conditions, usually bound with utilizing resources, waste sorting and recycling, organizing events.

6. Promoting ecotourism ideas. Tour operators promote ecotourism ideas due to their specific offer, declarations, and activities. Hence, ecotourism is constantly exposed in their promotion strategy.

\section{Tourism and the natural environment alliance?}

Tourism is strongly associated with the natural environment. The natural conditions drive its development, but exaggerated tourist traffic is known to negatively influence the environment.

The key factor influencing the alliance between tourism and the natural environment is environmental sensitivity (Chawla, 1998; Kollmuss, Agyeman, 2002, p. 251). Together with the ethical aspect, it has a considerable role in the decisions taken by tourism market participants.

Another factor is ecological awareness. It involves the knowledge and understanding of the environment, readiness to take action to protect it (Zuzek, 2017, p. 162). Depending on this awareness, the activities of tourism market participants more or less easily adjust to ecotourism assumptions.

The very knowledge of the impact of human behaviours on the natural environment is generally not sufficient to effectively inspire the market participants to manifest pro-ecological behaviours (Kollmuss, Agyeman, 2002, pp. 239-260). Often, pro-ecological attitudes are not shaped until strong emotions associated with a specific environmental issue are aroused.

Ecotourism can be a source of emotions and experiences. Emotions shape the bonds with the visited site, people, and culture, create responsibility. Experiences broaden the tourists' knowledge and evoke willingness to learn more.

\section{Conclusions}

1. One is never an ecotourist only when travelling. Ecotourism assumptions propagate into everyday life: one could suggest that ecotourism is a lifestyle. Ecotourists are characterized by high ecological awareness and environmental sensitivity.

2. As can be derived from the key ecotourism assumptions (tab. 2), tourism does not have to degrade the environment; on the contrary, it can measurably contribute to environmental protection (e.g. Morse, 2017; Nowacki, 2005; Tilden, 1977).

3. An alliance between tourism and the natural environment is possible. Care for the natural environment translates into care for human interests and long-term opportunities to satisfy man's needs (Barwicka, 2018, pp. 10-11).

4. Ecotourism can provide multidimensional benefit to all parties engaged, i.e. tourists, entrepreneurs, inhabitants, and the nature itself. More and more researchers (e.g. Ivanov, Ivanova, 2013; Weaver, 2001; Zaręba, 2010) call to allow the tourism of bigger organized groups to ecotourism, with some restrictions resulting from the care for the region being 
visited. The implementation of ecotourism ideas provides opportunities to eliminate many contemporary tourist dysfunctions.

5. Ecotourism is a relatively new area of scientific research. Special emphasis should refer to:

- identifying the conditions and tendencies in ecotourism development,

- analysing and describing the mechanisms of the ecotourist system, including the behaviours and relations of the market participants.

6. The specific research issues in the area of ecotourism are the following:

- What is the level and conditioning of the ecological awareness of the citizens of Poland and other countries in the context of ecotourism development?

- What does the development of interest in ecotourism in various countries depend on?

- To what degree is ecotourism a potential market with big opportunities to rise?

- What are the needs and behaviours of consumers defined as ecotourists? What changes can be expected?

- What are (should be) the attributes and contents of an original ecotourist offer? The issue of artificial (declarative, false) ecotourist offers.

- How should the current ecotourist offers in the Polish market be assessed? What changes and developmental directions can be observed?

\section{References}

Balmford, A., Beresford, J., Green, J., Naidoo, R., Walpole, M., Manica, A. (2009). A global perspective on trends in nature-based tourism. PLoS Biology, 6 (7), e1000144. DOI: 10.1371/journal.pbio.1000144.

Barwicka, K. (2018). Ekologiczne i humanistyczne aspekty turystyki zrównoważonej. Gospodarka Rynek Edukacja, 2 (19), 5-11.

Björk, D.P. (2000). Ecotourism from a conceptual perspective: an extended definition of a unique tourism form. International Journal of Tourism Research, 2 (3), 189-202, DOI: 10.1002/ (SICI)1522-1970(200005/06)2:3<189::AID-JTR195>3.0.CO;2-T.

Blamey, R.K. (2001). Principles of ecotourism. In: D.B. Weaver (ed.), The encyclopaedia of ecotourism. Wallingford: CABI Publishing.

Butler, R.W. (1999). Sustainable tourism: a state-of the-art review. Tourism Geographies 1 (1), 7-25.

Ceballos-Lascurain, H. (1987). The future of "ecotourism". Mexico Journal, 1, 13-14.

Center for Responsible Travel (2017). The case for responsible travel: trends \& statistics 2017. Washington, D.C.: Center for Responsible Travel. Retrieved from: https://www.responsibletravel.org/docs/The $\% 20$ Case $\% 20$ for $\% 20$ Responsible\%20Travel\%202017_Final\%20for\%20Release.pdf (29.07.2018).

Chawla, L. (1998).

Diamantis, D. (1999). The concept of ecotourism: evolution and trends. Current Issues in Tourism, 2 (2-3), 93-122. DOI: $10.1080 / 13683509908667847$.

Donohoe, H.M., Lu, X.-L., Wu, C.-Y. (2006). Conceptualizing ecotourism from a distinct criteria approach by using content analysis. Acta Ecologica Sinica, 4 (26), 1213-1220.

Donohoe, H.M., Needham, R.D. (2006). Ecotourism: the evolving contemporary definition. Journal of Ecotourism, 3 (5), 192-210, DOI: $10.2167 /$ joe152.0.

Fennell, D.A. (2014). Ecotourism, $4^{\text {th }}$ ed. London, New York: Routledge Taylor \& Francis Group.

Hawkins, D.E., Lamoureux, K. (2001). Global growth and magnitude of ecotourism. In: D.B. Weaver (ed.), The encyclopedia of ecotourism (pp. 63-72). Wallingford: CABI Publishing. 
Higham, J. (2007). Ecotourism: competing and conflicting school of thoughts. In: J. Higham (ed.), Critical issues in ecotourism. Understanding a complex tourism phenomenon (p. 1-19). Oxford: Butterworth-Heinemann. Retrieved from: https://booksite.elsevier.com/samplechapters/9780750668781/9780750668781.pdf (14.11.2017).

Ivanov, S.H., Ivanova, M.G. (2013). Mass ecotourism vs. eco mass tourism. Proceedings of the Sixth Black Sea Tourism Forum, October 2-4, 2013, Varna, Bulgaria; 78-90.

Koeman, A. (1998). Sustainable tourism and eco-tourism. Retrieved from: http://www.mekonginfo.org/assets/ midocs/0001574-environment-sustainable-tourism-and-eco-tourism.pdf (08.11.2017).

Kollmuss, A., Agyeman, J. (2002). Mind the gap: why do people act environmentally and what are the barriers to proenvironmental behaviour? Environmental Education Research, 3 (8), 239-260. DOI: 10.1080/13504620220145401.

Lu A.C.C., Gursoy, D., Del Chiappa, G. (2016). The influence of materialism on ecotourism attitudes and behaviours. Journal of Travel Research, 2 (55), 176-189. DOI: 10.1177/0047287514541005.

Morgan, D. (1999). Ecotourism - fad or future for tourism? Retrieved from: https://www.bgci.org/education/article/0371/ (30.07.2018).

Morse, B. (2017). The role of observational learning in developing ecotourists' environmentally responsible behavioural intentions. Master thesis. University of Michigan.

Nowacki, M. (2005). Interpretacja dziedzictwa w pracy przewodnika i pilota wycieczek. In: Z. Kruczek (ed.), Pilotaż i przewodnictwo - nowe wyzwania. Materiały z II Forum Pilotażu i Przewodnictwa (pp. 67-80). Cracow: Proksenia.

Sharpley, R. (2006). Ecotourism: a consumption perspective. Journal of Ecotourism, 1-2 (5), 7-22. DOI: $10.1080 / 14724040608668444$.

The British Ecotourism Market, UNWTO (2002). Ecotourism and protected areas. Retrieved from: http://sdt.unwto.org/ content/ecotourism-and-protected-areas (30.07.2018).

The International Ecotourism Society (2015). Ecotourism definition. Retrieved from: http://www.ecotourism.org/book/ ecotourism-definition (30.07.2018).

Tilden, F. (1977). Interpreting our heritage, $3^{\text {rd }}$ ed. Chapel Hill: University of North Carolina Press.

Twining-Ward, L., Li, W., Bhammar, H., Wright, E. (2018). Supporting sustainable livelihoods through wildlife tourism. Washington, DC: World Bank. Retrieved from: https://openknowledge.worldbank.org/handle/10986/29417 (29.07.2018).

Weaver, D.B. (ed.) (2001). The encyclopedia of ecotourism. Wallingford: CABI Publishing.

Whelan, C. (2013). Spotlight on sustainability: why is ecotourism special? Retrieved from: http://www.worldwildlife.org/ blogs/good-nature-travel/posts/spotlight-on-sustainability-why-is-ecotourism-special (14.11.2016).

Zaręba, D. (2010). Ekoturystyka, $3^{\text {rd }}$ ed. Warsaw: Wydawnictwo Naukowe PWN.

Zuzek, D.K. (2017). Świadomość ekologiczna przedsiębiorców jako element zrównoważonego rozwoju. Studia Ekonomiczne, 326, 162-171. 


\section{EKOTURYSTYKA JAKO CZYNNIK ZACHOWAŃ UCZESTNIKÓW RYNKU TURYSTYCZNEGO}

\begin{abstract}
SŁOWA KLUCZOWE
STRESZCZENIE

turystyka, ekoturystyka, rynek turystyczny, zachowania uczestników rynku

Celem artykułu jest wskazanie potencjalnego wpływu ekoturystyki na uczestników rynku turystycznego. Metodykę oparto na badaniach piśmiennictwa dotyczącego ekoturystyki i rynku turystycznego, dyskusjach i refleksji własnej. Wyniki wskazują, że ekoturystyka znacząco oddziałuje na świadomość i postawy uczestników rynku turystycznego. Może ona stanowić narzędzie ułatwiające sojusz turystyki ze środowiskiem przyrodniczym. Ekoturystyka może dostarczać wielowymiarowych korzyści turystom, przedsiębiorcom, lokalnym mieszkańcom oraz samej przyrodzie. W artykule wskazano też kierunki przyszłych badań nad ekoturystyką.
\end{abstract}

Translated by Iwona Kresak 